\title{
Oonf-701065-1
}

\section{COST ANALYSIS \\ OF \\ MULTIPLE POWER REACTOR SITING \\ AT HANFORD}

by

J. R. Young

J. B. Burnham

J. M. Batch

Battelle Memorial Institute

Pacific Northwest Laboratories

Richland, Washington

NOTICE

This report was prepared as an account of work sponsored by the United States Government. Nefther the United States nor the United Siates Atomic Energy Commission, nor any of their omployees, nor any of their cointractors, subcontrociors, or their omployees, makes ainy werranty, express or Implied, or aseumes any lozal linbility or responsibility for the eccuracy, completeness of usefulness of any/ information, epparatus, product or process disclosed, or represents that its use would not infringe privately owned rights.

This study was suggested and conducted by Battelie-Northwest as a contribution to orderly regional growth and development. It was presented to a meeting of the "rri-City Nuclear Industrial Councll on October 28, 1970, at Richland, Washington. 
TABHE OF CONTENTS

SUMMARY $\ldots \ldots \ldots \ldots \ldots \ldots \ldots \ldots \ldots \ldots \ldots \ldots \ldots \ldots \ldots \ldots, \mathbb{1}$

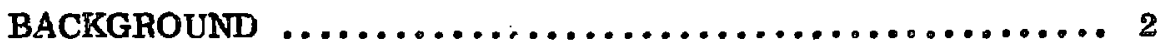

DETAILS OF THE STUDY .......................

Basic Assumptions $\ldots \ldots \ldots \ldots \ldots \ldots \ldots \ldots \ldots \ldots \ldots \ldots$

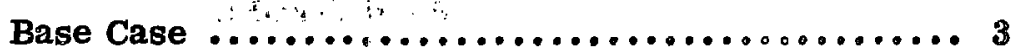

DUPLEX CaSe $\ldots \ldots \ldots \ldots \ldots \ldots \ldots \ldots \ldots \ldots \ldots \ldots, 3$

ADJACENT Case $\ldots \ldots \ldots \ldots \ldots \ldots \ldots \ldots \ldots \ldots \ldots, 4$

Method of Calculation $\ldots \ldots \ldots \ldots \ldots \ldots \ldots \ldots \ldots \ldots \ldots$ 7

RESULTS $\ldots \ldots \ldots \ldots \ldots \ldots \ldots \ldots \ldots \ldots \ldots \ldots \ldots \ldots \ldots \ldots \ldots, 8$

First Reactor $\ldots \ldots \ldots \ldots \ldots \ldots \ldots \ldots \ldots \ldots \ldots, \ldots$

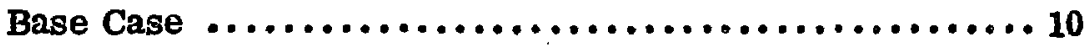

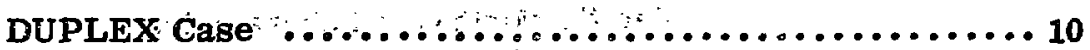

ADJACENT Case $\ldots \ldots \ldots \ldots \ldots \ldots \ldots \ldots \ldots \ldots \ldots \ldots \ldots \ldots$

Effect of Delays $\ldots \ldots \ldots \ldots \ldots \ldots \ldots \ldots \ldots \ldots \ldots \ldots \ldots \ldots \ldots 14$

Effect of Timing $\ldots \ldots \ldots \ldots \ldots \ldots \ldots \ldots \ldots \ldots \ldots \ldots \ldots \ldots$

ACKNOWLEDGEMENT $\ldots \ldots \ldots \ldots \ldots \ldots \ldots \ldots \ldots \ldots \ldots \ldots, 17$

APPENDIX $\ldots \ldots \ldots \ldots \ldots \ldots \ldots \ldots \ldots \ldots \ldots \ldots \ldots \ldots \ldots \ldots, 18$

Table A-1, - Industry Survey $\ldots \ldots \ldots \ldots \ldots \ldots \ldots \ldots \ldots \ldots$

Table A-2 - Breakdown of Capital Cost Savings $\ldots \ldots \ldots \ldots . .23$ 


\section{SUMMARY}

Significant capital cost savings can ive made in the construction of nuclear power plants if two reactors are built at a common site. Since considerable interest is being shown in locating commerelal powez plants at Hanford, Battelle-Northwest studied the savinge which might be made by building two reactors on a single Hanford site.

The most significant conclusions from this study are:

- Capital cost savings of $\$ 32$ million can be realized by bullaIng a DUPLEX - - two nucleax power plants constructed in a fully coordinated gequence and sharing a common control room, turbine gallery, service area, river pump house and cooling pond.

- Savinge of $\$ 15$ million are posaible on ADJACENT construction of the two plants winere construction is fully coordinated but only a river pump house and cooling pond are shared.

The eavings indicated in elther of these two creses will be reduced sigmifcantly if the need for power and the contruction schedule are not optimized. For example, if the DUPLEX is contracted for 1977 and 1978 conapletion and the time schedule for the project stretches out an additional year, the total costs will increase by about $\$ 41$ milition. This increase is caused about half by escalation and the other half by increased interest-durring-construction costs. 
If the demand for power is such that the capacity of both reactors could be used in 1977, there is a large incentive, because of escalation, to step up the construction schedule to bring both reactors on line as quickly as possible. If demand has been overestimated, though, and the extra capacity is built before it is needed, the fixed charges on the second reactor will rapidly consume the savings.

\section{BACKGROUND}

Power generation in the Northwest has been almost exclusively hyỏroelectric. However, additional suitable dam sites are almost nonexistent. Other means of generating electrical power must be found. Nuclear reactors are prime candidates for producing this power.

Nuclear power plant siting has received considerable study in the Northwest. A number of potentially suitable sites have been identified. Because public acceptance, or the lack of it, can cause crippling construction delays, a great deal of attention has been given recently to a Hanford site. As a result, during October 1970, the Washington Public Power Supply System (WPPSS) announced their intention to build a 1100 MWe nuclear power plant at Hanford for a September 1977 startup date. Other Northwest utllities have also indicated an intrarest in a Hanford site. Many of the nearly 100 reactors now belas butlt or in the design stage in the V. S. are part of complexess involving more than one rezctor. As part of the study reported here, a survey was made of multiple reactors scheduled for a common site In this decade. As is shown in Table A-1, over 60 percent of the reactors acheduled for startup between 1970 and 1977 will share a sites with at least one other reactor power plant. Savinge of construction coste and time necessary for site appzoval are prime reasons for these multiple reactor somplexes. 
Considering the above, Eattelle-Northwest felt that to assist orderly regional growth and development it was important to investigate the cost savings that could be achieved by building more than one reactor at a Hanford site. It should be understood that cost savings can be achieved at sites other than Hanford by fully coordinating the design and construction of dual reaetors. The Hanford site was chosen as an example because of current projections of jorthwest power needs and the presently incicated plans far building nuclear power plants.

\section{DETAIIS OF THE STUDX}

Basic Assumptions

Determination of the advantages from multiple reactor consiruction requires establishment of a realistic set of basic assumptions and study cases. In particular, it is desirable to have the results representative of not only the Hanford Plant, but also of other similar sites. At the same time, the number of caseg studied was kept small because of time and financial limitations.

Three cases were selected as best accomplishing the objectives of the study:

Base Case. Construction of two nuclear poiver plants at separate sites with no coordination of siting, construction or engineering.

DUPLEX Case. Construction of two nuciear power plants built af a single reactor compiex with maximum csordination of siting, construction and engineering. Both reactors and associated factilties would be located in the same building, Other facilities, such as the river pump hoisses, cooling ponds, recirculating water syetems, etc. , would be combined into single facilitles with anple capacity for the extire complex. (See Figure 1.) 
ADJACENT Case. Construction of two nuclear power plants built as separate plants but located a few hundred yards apart. It implies maximum coordimation of siting, construction, and engineering and the two reantors would use a common river pump house and cooling pond. (See Figure 2.)

The typical site for a reactor cołaplex at Hanford is assumed to be just east of the standby 100-D Area on the adjasint high ground. The heat would be dissipated in a cooling pond built further east in the low flatlands between 100-D and the former White Bluffs townsite. Preliminary anjlysis indicated that a cooling pond would be both technically and economically attrantive. Preliminary groundwater studies also indicate that there should be no detrimental effects on the Hanford Plant operations since the ponds would be confined to plant regions recently designated as being available for valimited release of water to the ground.

The reactors are assumed to be $1180 \mathrm{MWe}$ pressurized water reactors (PWRs) of current standard design. The gix year construction period for the first reactor is assumed to start eariy in 1971 and result in a reactor startup in 1977. The second reactor in each case would start up one year later. Construction of the second reactor nominally would start in 1972 , but it noust be realized that full coorditation of construction of the two plants actually results in an essentialiy gimultancous start on many of the major structures for bath plants.

Land is assiumed to cost $\$ 100$ per acre, a reascnable cost for the Hanford Project. It is assumed that the reactors are sited on the alluvium typical of the fanford production reactor sites. The land requirementi are 300 acres for each reactor site plus 1200 acres for the adjacent cooling pond. Nominal sealing of the cooling pond may be necessary to control warking of the riverbank, temperatures of seepage 
5.

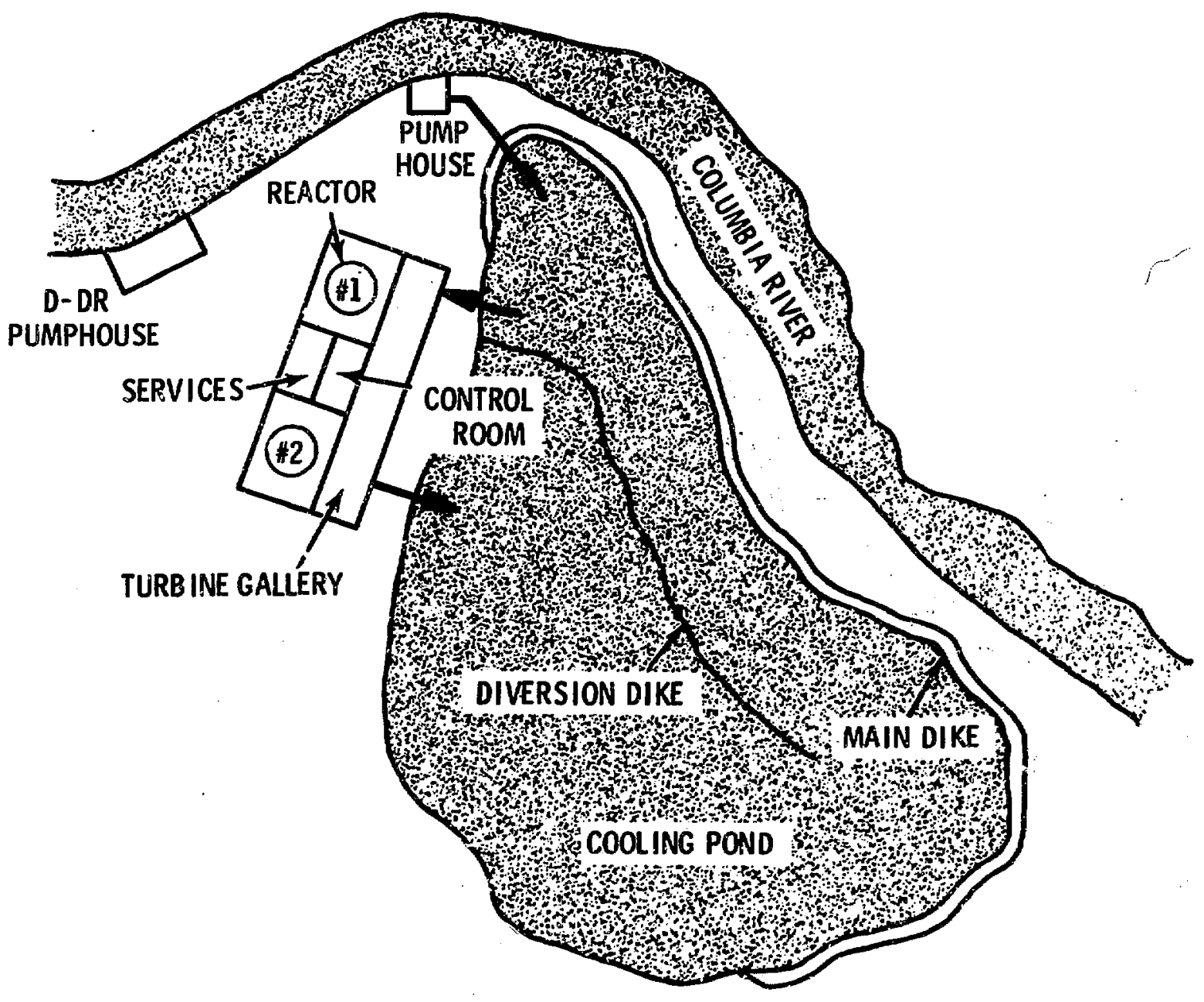

FIGURE 1.

Hanford Duplex Reactor Site 
6.

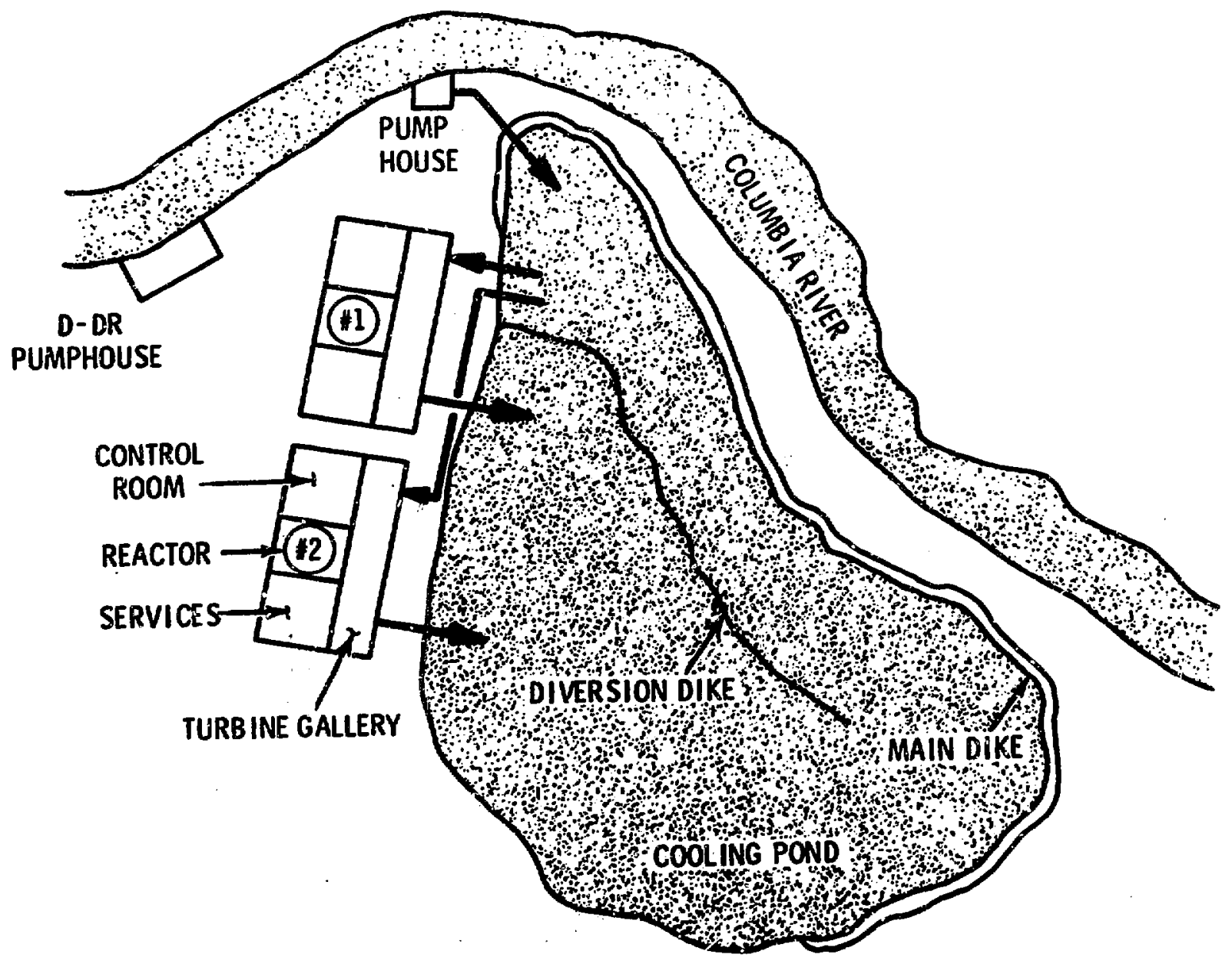

FIGURE 2.

Hanford Adjacent Reactor Site 
water going to the river or excessive makeup water pumping costs. This sealing might be accomplished by: adding clay to the pond: water or by construction of a slurry trench adjacent to the retaining dike.

The construction costs were escalated by assuming continuation of the average escalation rates of the past six years. These were 4.5 percent per year for factory equipment, 10.5 percent for site labor and 4.0 percent for aite materlals. These result in an overail: average escalation rate for direct construction costs of about 6. 0 percent. Since indirect construction costs are based on total direct costs, the indirect costs also escalate at this 6.0 percent rate. Because the average escalation varies in accordance with the mix of equipment, labor and materials, these cosis were escaíated separately for each case studied.

The interest rate during construction was assumed to be 6.5 percent.

\section{Method of Calculation}

Determining the construction costs for a nuclear power plant requires estimating the costs for thousands of material and labor items. As a simplification, systems of standard cost accounts have been established for the various cost activities and centers. The definitions of these accounts have been chosen such that correlation of the cests with plant type and size is possible. The cost estimation, however, still is complex because there are eleven main accounts and a total of approximately 150 subaccounts.

Enough nuclear power plant construction costs have become avallable to allow detailed analyais oy gize, type and lockition of the plant. These costs have been correlated and eomiphterized with two todes, the CAPCOST ${ }^{1}$ cnde of Battelle-Northwest

1 BNWL-882, CAPCOST, A Program to Calculate Escalated Nuclear Powor plant Cophtal Cosis, T. A. Shank, E. L. Kelley, Jx. ante, B. Burnham, Jr., tuly 1968. 
and the CONCEPT ${ }^{1}$ code of the Computer Technology Center and the Oak Ridge National Laboratory. Both codes estimate the escalated total costs for nuclear power plants at various locations in the United States.

The CAPCOST code estimates the total escalated cost for a nuclear power plant on the basis of correlations of historical construction costs. Included is a breakdown of the costs into total direct and indirect costs plus construction labor, factory labor and materials. These costs are calculated for any of 75 typical locations throughout the United States and are escalated to represent actual costs for the selected reactor startup year.

The CONCEPT code makes a detailed calculation of the capital costs broken down inio factory equipment, site labor and site material costs for each of the capital cost accounts. The account structure and definitions are based on the NUS- $531^{2}$ guide, a standard reference document for the USAEC. At present, the CONCEPT code can calculate the total capital cost for a plant constructed at any one of twenty-four typical central cities throughout the United States and Canada. The resultant capital costs are escalated to the year that construction starts. The capability to escalate during the construction period is currently being added to the code. This correction was hand calculated for this study.

\section{RESULTS}

The reactor complex capital costs were determined by starting with the basic construction account costs provided by the computer codes, correcting these

\footnotetext{
${ }^{1}$ CTC-18, CONCEPT (Phase I): Computerized Nominal Cost Estimates for PWR-

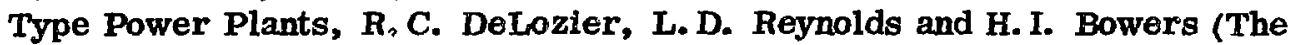
Computer Technology Center and Oak Ridge National Laboratories--to be published).

2NUS-531, "Guide for Economic Fvaluation of Nuclear Reactor Plant Designs", NUS Corporation, January 1969.
} 
for differences in plant design and then escalating as appropriate for the assumed construction period. A stepwise approach was taken. The costs were first determined for a single reactor complex; these basic costs were adjusted to ob tain the cost of the second reactor for each case.

A summary of these capital costs appears in Table I. A detailed breakdown of the costs by accounts is presented in Table A-2 of the Appendix. A discussion of each reactor complex and the reasons for cost differences is presented below.

\section{First Reactor}

The basic cost data obtained by computer calculations represent the costs for building a PWR with once-through river water cooling, good foundation conditions requiring no bedrock excavation and a forty-hour work week with Seattle, Washington, labor costs. Most of the account costs would be the same for a Han' ird reactor complex as for the typical Seattle-area reactor. The primary differences ore as follows;

Labor Items. Site labor rates were increased by five percent to represent current travel allowence at Hanford and to accommodate a nominal amount of overtime work.

Land and Land Rishts. Assumed purchase of 1500 acres of land at $\$ 100$ per acre.

Relocation. Assumed $\$ 1,000,000$ for relocation of utilities, etc. Intake and Discharge Structures. Added a 200,000 gpm river pump house for makeup water to the cooling pond. Other Bulldings. Added a $\$ 500,000$ visitors center. 
Shipping. Added $\$ 500,000$ for extra equipment shipping costs.

Heat Removal System. Added an 1100 acre pond (1200 acres of land are required) and the equipment in the river pump house.

\section{TABLE I}

Summarized Construction Costs Hanford Power Reactors

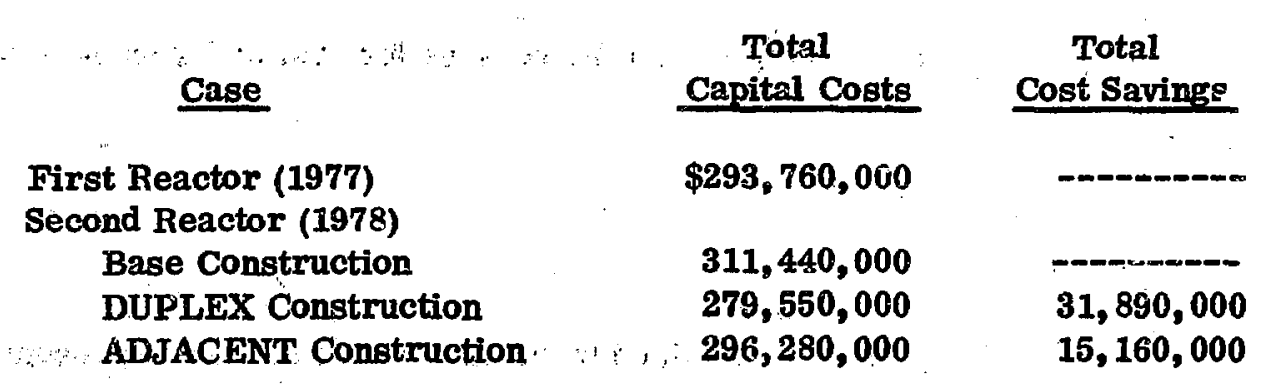

Base Case

This second reactor would be butlt with no coordination of siting, engineering or construction. The costs were obtained by assuming that construction would start ope year after the flixt reactor. The second reactor was calculated to cost $\$ 311,440,000$. The cost of this second reactor becomes the basis for the determination of savings for the other two cases.

\section{DUPLEX Case}

DUPLEX construction (deseribed earlier) assumes maximum coordination of planning and use of common facillties.

The cost of the second reactor in this case is calculated to be $\$ 279,550,00$ । Compared to the base case, this is a Bavings of $\$ 31,890,000$ or 10.2 percent. The 
details of these savings are shown in Table $I$. The reasons for these differences are as follows:

Site Improvements and Facilities. Most of the site preparation costs for the first plant would also be adequate for the second. Both reactors could be served by the same roads, railroads, etc. with only minor cost increases.

Buildings. Common construction of the one large main building permits both economies of scale plus the elimination of duplicate facilities. Offsetting some of these advantages are the problems associated with more phases of construction occurring at the same time and the isolation of the first reactor systems during startup preparations while major construction is continuing in the second reactor system.

Construction of Heat Removal System. Common construction of the recirculating water and river pump houses plus the intake and discharge conduits results in economies of scale. Construction of a single 2200 acre cooling pond saves some diking expenses.

Reactor Plant Equipment. Construction of a second identical reactor plant is expected to reduce the site labor costs for this account by about four percent biecause of better work scheduling and improved construction labor training.

Miscellaneous Plant Equipment. Use of a common turbine gallery pexmits elimination of one overheacl crane. Economies of scale are realized in the air and water service systems, comminications systems, furnishings, etc. 
Other Direct

$$
3,460,000 \quad 1,850,000
$$

$2,420,000$

900,000

Total Direct

$16,140,000$

$5,530,000$

92

Engineering

$6,020,000$

$6,020,000$

94

Interest during Construction

$$
4,890,000 \quad 2,330,000
$$

Other Indirect

$4,840,000 \quad 1,280,000$

Total Indirect

$15,750,000$

$9,630,000$

Combined Total

$31,890,000$

$15,160,000$

Percent Savings

10.2

4.9 
Reactor Engineexing. Most of the Gngineerirg for the first reactor plant would be applicable to tho second plant. Examples are site selection, design, environmental studies, subsurface investigetions, procurement, preparation of test and startup procedures, and inspection. Other activities would be reduced in scope because of reduction of the total amount of construction (field inspection, preparation of asbuilt drawings, etc.).

Interest During Construction. Interest during construction is proportional to the total plant costs and the construction period. It was conservativaly assumed that the total construction pariod for both reactors would be gix years, even though one could advance substential arguments for a shorter construction period for the second reactor in a duplex facillity.

\section{ADJACENT Case}

ADJACENT constsuction assumes maximum coordination of planning and construction, but with the two reactor complexes buflt, separately a few hundred yards apart. The only common factlities would be the cooling pond, the river pump house and remporary construction facilities. The cost of the second reactor in this case was calculated to be $\$ 296,280,000$ for a savings of $\$ 15,160,000-$ or a 4,9 percent reduction.

The cost savings would be realized primarily from coordination of construction activities and construetion of the common cooling pond. The primary savings 
in construction costs are summarized in Table II. The reasons for the cost differences between the ADJACENT and DUPLEX cases are as follows:

Site Improvements and Facilities. More site preparation is required because of the larger construction area. All roads, railroads, etc. must be longer.

Buildings. The advantages of common buildings and elimination of duplicate facilities no longer are realized.

Construction of Heat Removal System. Conetruction of two recirculating water systems is more costly than construction of one larger system. Miscellaneous, The advantages of common cranes and facilities are not realized.

Interest During Construction. The interest during construction would be higher because of the higher direct costs.

\section{Effect of Delayg}

Delays can occur during a large construction project at any time and for any of several reasons. Typical causes are labor difficulties, interventions, licensing and equipment delays.

The delays may increase the total construction cost in the following mamer:

1. Increased interest during construction.

2. Increased ealary costs for management during delays.

3. Increased lainor costs because of work inefficiencies related to preparing for and recovering from the delay periods.

4. Overtime expenses to recover lost time.

5. Increased salary and equipment costs due to escalation. 
15.

Obviously, the total extra cost; due to a particular delay will depend on the cause and the nature of the delay. A complete shutdown of a job because of a strike will iave a different effect than late delivery of a major equipment itena such as the reactor vessel.

In this particular analysis the effect of delays will be illustrated by assuming that the delay is a complete stretchout of the entire DUPLEX project such that the total construction time is increased by one year. It aloo is assumed that there is no significant increase in total work performed or quantity of materials used. in that case the total cost increase is due primarily to the effects of escalation and increased interest during construction.

The total extra cost of a one-year stretchout would be $\$ 40,700,000--$ an increase of 6.7 percent.

\section{Effect of Timing}

Realization of maximum savings from coordinated construction of a two reactor complex requires precise planning of the reactor construction schecule. Important factors that must be considered are:

1. Demand ior electricity.

2. Scheduling of construction activities.

3. Escalation of construction costs.

Maximum benefit from coordinated construction activities is realized by reactor startups from six to efghteen, months apart. A shorter perlod between startups results in a reduction of efficiency. Longer periods between startups result in the disbanding of experienced crews and the need to restart activitles. 
Escalation reduces the serings in direct proportion to the time between startups. Delays could eliminate all savings. We must be careful though, in talklug about reductions in savings die to escalation. If the second reactor of a DUPLEX design is delaye no longer than the other independent reactor to which it is being compared, they would boih escalate at the same rate and the effects of escallation would cancel oul A more cletailed stuity of this effect inust include the xelative probability of dulay at each of the sites being conmared. (It is logical to assume that delays in the second reactor of a DUPLEX are less likely than in an independent site.)

The effects of these three parameters are illustrated in Figure 3 for the DUPLEX case with the second reactor being required one year after the flisgt. This highly qualitative curve is typical of the ones that utility executives frequently must evaluate. Such curves aje only as accurate as the general forecasts of future power demiand.

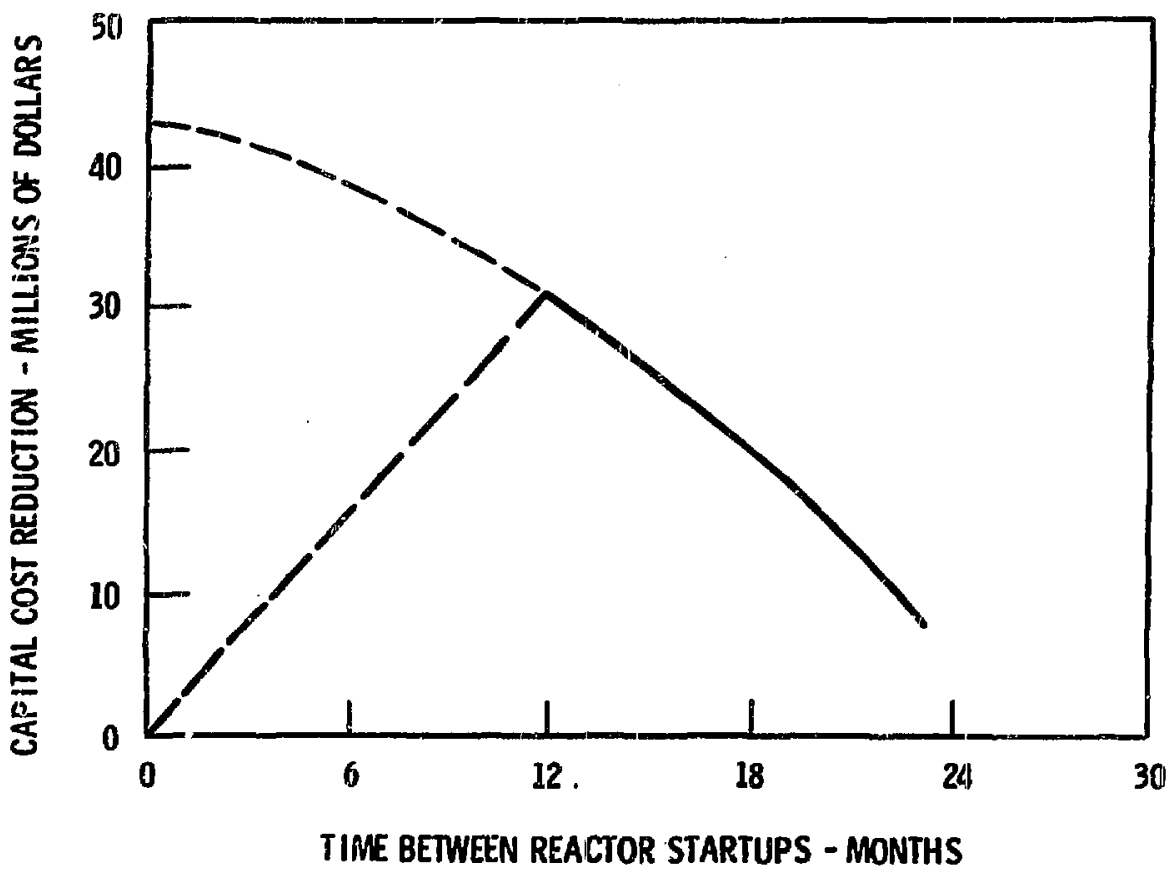

FIGURE; 3 .

Estimated Capital Cost Savings Duplex Resetor Construction 
While Nigure 3 is only qualitative, it illustrates the factors which effect the planning. The solid portirn of the curve is based on assumed startup of the second reactor one year after the firgt reactor to satisfy the forecast demand. Delay of the second reactor startup beyond one year is lllustrated by the solid curve to the right. This curve slopes downward because of decreased construction efficiency, increased interest during construction and cost escalation. As mentioned sariller, a different point of view could mitigate the effects of escalation and make the curve flatter. If the cost of replacement power (hardly 2 capital cost) were tncluded, the curve would be steeper.

If the demand for power is such that the second reactor's capacity can be used earlier than the indicated 12-month delay, there is a significant further savings to be realized as indicated by the dotted line sloping upwards. These cost savines? arise from less escalation and interest dusing construction; they are partially offset by a reduction in construction work efficiency.

The other dashed part of the curve, Lloping downward to zero savings, inustrates the problem of miscalculation of demand. If the demand is overestimated and the second reactor is completed too s0on, the fixed charges on the ldle capacity rapidly exce savinge.

\section{ACKNOWLEDGEMENT}

Appreciation is expressed for the cooperation of Messrs. H. I. Bowers and M. L. Myers of the Oak Ridge National liahoratory in providing basle economic data, multiple reactor cost relationshipe and the escalation factors ueed in this analysis. 
18.

APPENDIX

TABULATED DATA

Table A-1

Results of Industry Survey

Table A-2

Detailed Breakdown of Capital Cost Savings 


\section{Beactor/Location}

DRESDHN STATION Morris, Ilinols (Kankakee and Dep Pigines R.) COADOVA STATPON (QUAD CITLES) Cordova, Illinois (Misistesipgi ho) BROWHYS FERRY STA. Bromn's Ferry, Ala. (Wheeler Reservoir, Tomosee River)

PACH BOTIOM 2,3 Peach Bottom, PA (Conowingo Dam)

BRUNSWICK STATYON Near Wilmington, S. Carolina (Estuary, Cape Fear River)

EDWDN I. HATCR STA. Baxiey, Ba. (Altamaha River)
Owner/Operator

Commonwealth Ed,

Do

\begin{tabular}{l}
\hline 1970 \\
715 \\
715 \\
\\
\\
715 \\
715
\end{tabular}

Year of Operation \& Net MWe of Reactor

Commonwealth Fd. $\quad 715$ Illinois G8E

$1075 \quad 1075$

Tennesisee Valley Authority TVK

1075

1065

1065
Delaware Valley

viluties

(Atlantic City

Electric, Phila.

Electrie.)

Carolina $\mathbf{P}$ \& $\mathbf{L}$

Georgia Power Co. (Member Southern Company systom) 
Refactor/Iocation

INDIAN POINT $-4,5$

Cortland, N. Y.

(Hudson River)

IA SALIE COUNTY STA. Seneca, IIl. (Minois River)

ZIMMER STATIO
Ohio, Near Moscow
(Ohio River)
:
LIMERICK STA.
Near Pottstown, Pa.
(Schuyllil River)

PPEC BTATDN Site not. unnounced

INDLAN POTNT STA. Buchanan, N.Y. (Hudson River)

SAN ONOFRE STATICA (CAMP PENDLETON) San Clemente, Cal. POINT BEACH BTATION Two Creeks, Wis. (Lake Michigan)
Owner/Operator.

Consolldated Ed.

Commonwealth Ed.

Cincinnati G\&E

Columivus \& South

Ohio Electric,

Dayton I \& L

Philadelphia

Electric

Pennoylvania

Power \& Light

Consolidated Ed.

Do.

S. Calif Edison, San Diego G \& E

S. Calif. Ed.

Wisconsin Mtchigan Power Co. WMPCO
1065

$1100 \quad 1100$

Year of Operation \& Net MWe of Reactor

\begin{tabular}{|c|c|c|c|c|c|c|c|c|c|}
\hline 1970 & 197 & 1972 & 1973 & 1974 & $\underline{1975}$ & 1976 & 1977 & 1978 & 979 \\
\hline
\end{tabular}

$840 \quad 840$
1100

\section{8}

$873 \quad 965$ 


\begin{tabular}{|c|c|c|c|c|c|c|c|c|c|c|c|}
\hline & & \multicolumn{10}{|c|}{ Year of Operation \& Net MWe of Reactor } \\
\hline Reactor/Location & Owner/Operator & $\underline{1970}$ & 1971 & 1972 & $\underline{1973}$ & $\underline{1974}$ & 1975 & 1976 & 1977 & 1978 & $\underline{1979}$ \\
\hline $\begin{array}{l}\text { TURKEY POINT STA. } \\
\text { Turkey Point, Fla. } \\
\text { (Biscayne Bay) }\end{array}$ & Florida P \& I & & $\begin{array}{c}688 \\
\vdots\end{array}$ & 688 & & & & & & & \\
\hline $\begin{array}{l}\text { OCONEE STATION } \\
\text { Lake Keowee, } \\
\text { s. Carolina }\end{array}$ & Duke Power Co. & & 839 & 839 & 847 & & & & & & \\
\hline $\begin{array}{l}\text { SURREY STATION } \\
\text { Hog IGland, Vq. } \\
\text { (Inames Rirer) }\end{array}$ & $\begin{array}{l}\text { Virginia Electric } \\
\text { Power Co. VËPCO }\end{array}$ & & 783 & 783 & & & & & & & \\
\hline $\begin{array}{l}\text { PRATRIS ISLAND STA. } \\
\text { (RED WING STATTON) } \\
\text { Red WIng, Minn. } \\
\text { (Misisisippl R.) }\end{array}$ & $\begin{array}{l}\text { Northern States } \\
\text { Power } \\
\qquad\end{array}$ & & & $\mathbf{5 5 0}$ & & 550 & & & & & \\
\hline $\begin{array}{l}\text { DIABLO CANYON STA. } \\
\text { San Luis Oblepo } \\
\text { Cointy, Calle } \\
\text { (Pacific Ocenn) }\end{array}$ & $\begin{array}{r}\text { Pacific G \& } \mathbf{E} \\
\quad\end{array}$ & & & & 1060 & 1060 & & & $\therefore$ & & \\
\hline $\begin{array}{l}\text { SEQUOYAH STATION } \\
\text { Chickamaliga } \\
\text { Lake, Termessee }\end{array}$ & $\begin{array}{l}\text { Tonneasee Valley } \\
\text { Authority: }\end{array}$ & & 。 & & 1175 & 1175 & & & & & \\
\hline $\begin{array}{l}\text { COOK STATION } \\
\text { Bridgman, Mich. } \\
\text { (Lake Michigan) }\end{array}$ & $\begin{array}{l}\text { American Electric } \\
\text { Power (Indiana \& } \\
\text { Mich. Electric Co.) }\end{array}$ & & & 1060. & 1060 & & & & & : & \\
\hline
\end{tabular}


MULTIPLE REACTORS ORDERED FOR COMMON SITE

- Continued -

Year of Operation \& Net MWe of Reactor

Reactor/Location

CALVERT CLIFFS STA. Maryland

(Chesapeake Bay)

NORTH ANNA STATION North Anna River, Va.

LAKE NORMAN STA. Lake Norman (near Davidson), N.C. Artificial Lake

THTEE MII E ISI.AND. Near Harrisburg, $\mathbf{P a}$. (Stsqquehanna R.)

\section{WATTS BAR DAM} Decatur, Tenn. (Tennessee River)

TVA STATHON (Site not announced)

\section{Total}

Single plants

Total Capacity Added
Owner/Operator

Baltimore G \& E

Virginia Electric Power Co.

Duke Power Co. Contract award November 1969

Metropolitan Ed. , Reading, Pa.

Temessee Valley Authority

Tennessee Valley Authority

$1970 \quad 1971 \quad 1972$

1973

800

$\underline{1974}$

1975

$\underline{1976}$

1977

$\underline{1978 \quad 1979}$

800

$\begin{array}{llllllllll}\overline{3315} & \overline{5745} & \overline{6943} & \overline{8562} & \overline{4368} & \overline{4603} & \overline{6970} & \overline{8990} & \overline{1230} & \overline{1100} \\ \frac{2280}{6195} & \frac{2357}{8102} & \frac{5815}{12758} & \frac{8695}{17257} & \frac{3835}{8203} & \frac{5620}{10223} & \frac{2700}{9670} & \overline{8990} & \overline{1230} & \overline{1100}\end{array}$

$1970-1977$

Multiple Reactors, Common site Single Reactors

Total Net MWe
51,776

31,902

83,678

Multiple Reactors - 61.9 percent of total. 
TABLE A-2

HANFORD POWER REACTOR COSTS MULTIPLE REACTOR CONSTRUCTION

Basis: 1971 start, six year construction period, one year between reactor startups

Account

Number

20

201

202

211

212

213

214

215

218
Land \& Land Rights

Land \& Privilege Acq. Relocation of Bldgs., Utilities, etc.

Account Total

1,150

$.1,219$

1,187

1,187

First

Reactor (Separaite

Second Reactor Cost $(8000)$

Cost $1 \$ \mathrm{COO}$

\section{Duplex}

Design
Adjacent

Design $\begin{array}{r}150 \\ 1,000 \\ \hline\end{array}$

159

1,060

127

1,060

127

$\underline{1.060}$
Structures \& Facilities

Site Improvements \&

Facilitles

Reactor Building

Turbine Building

Intake \& Discharge

- Structures

Reactor Auxtliaries

Bldg.

Other

Contingency

Spare Parts

Account Totel
2,160

2,334

350

1,167

13,321

14,369

10,405

11,168

2,371

4,650

14,369

2,214

3,495

13,650

11,158

4,313

3,262

$\begin{array}{r}8,002 \\ 84 \\ \hline 41,468\end{array}$

10,600

2,764

81

38,520
2,398

700

1,534

1,223

4,650

2,967

2,220

2,754

62
31,208

80 
Account

Number

22

23

231

232

233

234

235

236
24

241

242

243

244

245

246

Electric Plant Equip.

Turbine Plant Equip.

Turbine Generators

Heat Removal Sys.

45,933

8, 108

48,147

8,670

6,565

6,982

seed Heating Sys.

8, 442

8,981

5,388

5,804

1,035

1,106

Duplex

Adjacent

Other Turbine

Plant Equipment

Instrumentation \&

Control

Contingency

Spare Parto

3. 284

3,436

639

Account Total 79,347

83,765

$86_{0} 277^{*}$

86, $277^{*}$

Design

Degign Design


25.

Account

Number

25

251

252

253

254

911

912

913

92

921

922

93

981

932

933

94
First

Reactor

Account Title

Miscellaneous Plant

Equipraent

Transportation \&

Lifting Equipment

Air \& Water

Service Systems

Communications

Equipment

Furnibhings and

Fixtares

Continzency

Spare Parts

Account Total

TOTAL DIRECT COSTS

216,085

Construction Facllities,

Equipment \& Services

Temporary Fachl.

Construction

Equipment

Construction

Services

Account rotal

3,397

2,050

10.834

Account Total 12,384

Other Costs

Taxea \& Insurance

Btaff Training \&

Plant Startap

cumers GaA

Account Total

75

$\begin{array}{r}14,190 \\ 1,510 \\ 1,169 \\ \hline\end{array}$

16,869

19,086

47,798

82,822

311.496

16, 259

1,600

1,238

18,007

17,678

298,760
Second Reactor Cost (\$000)

Base Case

(Separate

Duplex Adjacent

Construction)

691

280

757

121

62

628

324

188

19

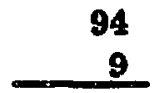

3,055

1,526

3,055

229,114

212,972

223,589

1,491

298

1,198

121

63

63

1,93

1,382

1,984

8,546

1,743

3, 190

2,182

1,492

1, 482

10.749

5. 374

5.374

12,881

6,866

6,886

18,862

14,600

530

I. 838

928

2.238

15,320

17,171

TOTAL INDIRECT COSTS 